\title{
Realization of the bioresource potential of the middle late hybrid of corn Beshtau in the steppe zone of the Chechen republic
}

\author{
A.G. Amaeva ${ }^{1,2, *}$, N. L. Adaev ${ }^{1,2}, V . N$. Bagrintseva $^{3}, J . H$. Aiskhanova $^{1}$, and K.M. \\ Salamova ${ }^{1}$ \\ ${ }^{1}$ Federal State Budgetary Educational Institution of Higher Education Chechen State University named \\ after A.A. Kadyrov, Grozny, Russia \\ ${ }^{2}$ Federal State Budgetary Scientific Institution" Chechen Research Institute of Agriculture", Grozny, \\ Russia \\ ${ }^{3}$ FGBNU All-Russian Research Institute of Corn, 357528 Pyatigorsk, st. Ermolova, 14b, Russia
}

\begin{abstract}
The article presents the results of studying the bioresource potential of the medium-late hybrid of corn Beshtau at the All-Russian Research Institute of corn on dry land and at the Chechen Research Institute of Agriculture on irrigation. In the steppe zone of the republic, against the background of the use of irrigation, the application of mineral fertilizers at a dose of N90P120K60 in combination with pre-sowing seed treatment with the agrochemical Bioplant Flora $(1.01 / \mathrm{t})$ and foliar top dressing with a tank fertilizer mixture Kristalon (3 kg / ha) + Brexil Zn $(0$, $15 \mathrm{~kg} / \mathrm{ha})+$ urea $(7 \mathrm{~kg} / \mathrm{ha})$ showed high efficiency in realizing the potential of the Beshtau hybrid. Due to irrigation and the use of these fertilizers, it turned out to be possible to increase the grain yield of the Beshtau corn hybrid to $12 \mathrm{t} /$ ha. The application of mineral fertilizers to the soil at a dose of N90P120K60 in combination with foliar feeding of plants with the agrochemical Bioplant Flora at a dose of $1.01 /$ ha in 5 leaves and $2.01 /$ ha in 8 leaves increased the starch content in the grain from 62.63 to $72.08 \%$, protein - from 10.65 to $12.28 \%$.
\end{abstract}

\section{Introduction}

Corn is a high-yielding grain and forage crop. Due to accumulation of a large amount of organic matter within the growing season, plants show a high need for water and mineral nutrients. Lack of water leads to significant losses in grain yield [1].

The most common and effective way to meet the needs of corn plants for nutrients and to increase productivity is application of mineral fertilizers to the soil [2-6]. In addition to traditional fertilizers, plant nutrition with various agrochemicals is now of great importance in the nutrition system. The modern agrochemicals market is represented by a variety of organic, organomineral and mineral fertilizers containing not only basic nutrients (nitrogen, phosphorus, potassium), but also a complex of microelements, organic acids,

\footnotetext{
*Corresponding author: aset-6666@mail.ru
} 
phytohormones. According to many researchers, use of such fertilizers can significantly increase the yield of green mass and corn grain [7-9]. Mineral fertilizers and agrochemicals for foliar dressing also significantly improve the quality of corn grain [10-12].

\section{Materials and Methods}

Scientific research was carried out at the All-Russian Research Institute of Corn in 20122014 and the Chechen Research Institute of Agriculture in 2015-2017. We studied the potential yield of a mid-late hybrid of Beshtau corn bred by All-Russian Research Institute of Corn in different soil and climatic conditions.

The experimental field of the All-Russian Research Institute of Corn is located in the zone of sufficient moisture in the Stavropol Territory. Soil - ordinary calcareous heavy loamy chernozem. The average long-term rainfall for the growing season of corn is 343.6 mm, including: 79.4 in May; June - 87.1; July — 70.4; August - 58.7; September $-48 \mathrm{~mm}$.

The experimental field of the Chechen Research Institute of Agriculture is located in the steppe zone of the Chechen Republic. The soil is meadow-chernozem, calcareous, weakly humified, weakly washed away. The average long-term rainfall for the growing season of corn here is $355 \mathrm{~mm}$, including: 82 in May; June — 95; July — 74; August — 62; September $-42 \mathrm{~mm}$.

The climatic conditions of the steppe zone of the Chechen Republic, in comparison with the zone of sufficient moisture in the Stavropol Territory, are characterized by uneven moisture in the middle of summer, long periods of dryness without precipitation.

Beshtau is a medium-late simple hybrid of corn for universal use, both for grain and for silage. The plants are tall, well leafy, with a strong stem, and are distinguished by their permanent flowering capacity. The hybrid is included in the State Register of Breeding Achievements approved for use in the Russian Federation since 2012.

The commercial grain of the hybrid is tooth-like. The grain contains $69.85 \%$ starch, $8.17 \%$ protein, $3.95 \%$ fat, $2.28 \%$ sugar, $1.12 \%$ fiber, $0.77 \%$ ash. The value of the grain of the Beshtau corn hybrid lies in the increased starch content and its suitability for production of starch and alcohol.

The objective of the study was to identify the reaction of the medium-late hybrid Beshtau under irrigation to mineral fertilizers, the effect on seed material and crops with agrochemicals in order to implement its genetic potential in the Chechen Republic.

\section{Results and Discussion}

In an experiment conducted in the zone of sufficient moisture in the Stavropol Territory to test corn hybrids of the All-Russian Research Institute of Corn, the Beshtau hybrid showed the highest yield of green mass and grain [13]. In addition, this hybrid was highly responsive to nitrogen fertilization (Table 1).

On average, over 3 years of testing from nitrogen fertilization at a dose of N60, the plant height increased by $11 \mathrm{~cm}$, the yield of green mass - by $6.0 \mathrm{t} / \mathrm{ha}(12.8 \%)$, grain - by $0.75 \mathrm{t} / \mathrm{ha}(7.0 \%)$.

In the steppe zone of the Chechen Republic, the factor limiting the yield of corn is moisture availability [14]. As it is known, corn consumes a large amount of water within the growing season. In the experiment carried out at the Chechen Research Institute of Agriculture, the total water consumption of the mid-season hybrid Krasnodar $385 \mathrm{MB}$ on average for 2010-2012 on dry land it was equal to $3,207 \mathrm{~m}^{3} /$ ha, and on irrigation it reached $5,790 \mathrm{~m}^{3} /$ ha [14]. 
Table 1. Plant height and yield of the Beshtau corn hybrid without fertilizers in the experiments of the All-Russian Research Institute of Corn

\begin{tabular}{|l|c|c|c|c|}
\hline Indicator & 2012 & 2013 & 2014 & On average \\
\hline \multicolumn{5}{|c|}{ No fertilizers } \\
\hline Plant height, cm & 266 & 250 & 245 & 254 \\
\hline Productivity of green mass, $\mathrm{t} / \mathrm{ha}$ & 51.6 & 40.7 & 48.7 & 47.0 \\
\hline Grain yield, t/ha & 12.02 & 11.35 & 8.76 & 10.71 \\
\hline \multicolumn{5}{|c|}{$\mathrm{N} 60$} \\
\hline Plant height, cm & 275 & 256 & 263 & 265 \\
\hline Productivity of green mass, $\mathrm{t} / \mathrm{ha}$ & 56,8 & 48.7 & 53.5 & 53.0 \\
\hline Grain yield, t/ha & 12.45 & 12.09 & 9.83 & 11.46 \\
\hline
\end{tabular}

Without irrigation in this area, corn grain yields are very low. So, on average for 20102012, without irrigation and use of fertilizers, the grain yield of domestic corn hybrids Krasnodar $382 \mathrm{MB}$ and Krasnodar $385 \mathrm{MB}$ varied within 2.3-2.8 t/ha (Table 2).

Irrigation of $500-800 \mathrm{~m}^{3} /$ ha with an irrigation rate of $2,050-2,800 \mathrm{~m}^{3} /$ ha to maintain soil moisture at the level of $70-80 \% \mathrm{HB}$, even without use of fertilizers increased the yield of hybrids on average for 3 years by 1.9-2.0 times.

Importance of irrigation was especially great in the extremely dry 2011, when 1.7$2.8 \mathrm{t} / \mathrm{ha}$ of grain were obtained without irrigation on a fertilized background. By artificially improving the moisture supply of corn, the grain yield of the Krasnodar 382 MB hybrid increased 3.8 times, and the Krasnodar $385 \mathrm{MB}-6$ times.

In the steppe zone of the Chechen Republic, irrigation combined with an efficient fertilization system is the most important reserve for increasing corn yields.

In conditions of irrigation, the importance of the nutrition system increases, which shall be considered as a priority element of the corn cultivation technology. The use of macroand micronutrient fertilizers, as well as other agrochemicals, in turn, is a condition for the effective use of irrigation.

In order to use the bioresource potential of the high-yielding corn hybrid Beshtau, the Chechen Research Institute of Agriculture studied the effect on the yield and grain quality of different options for using mineral fertilizers and agrochemicals for pre-sowing seed treatment and foliar top dressing of plants during the growing season.

The decisive importance provided use of a complete mineral fertilizer in a dose of N90P120K60, due to which the yield of the Beshtau hybrid in 2015 increased by $1.2 \mathrm{t} / \mathrm{ha}$ (14.1\%), in 2016 — by $1.6 \mathrm{t} / \mathrm{ha}(18.8 \%)$, in 2017 — by $2.8 \mathrm{t} / \mathrm{ha}(36.8 \%)$. On average, in addition to the control, $1.9 \mathrm{t} / \mathrm{ha}(24.1 \%)$ were obtained.

Two foliar top dressing with Bioplant flora fertilizer against the background of mineral root nutrition gave an additional 1.6 t/ha over 3 years, which was $15.8 \%$ compared to the N90P120K60 option.

Table 2. Productivity of corn hybrids depending on irrigation and fertilization.

\begin{tabular}{|c|c|c|c|c|c|c|c|c|}
\hline \multirow[t]{2}{*}{ Irrigation } & \multicolumn{2}{|c|}{2010} & \multicolumn{2}{|c|}{2011} & \multicolumn{2}{|c|}{2012} & \multicolumn{2}{|c|}{ On average } \\
\hline & 1 & 2 & 1 & 2 & 1 & 2 & 1 & 2 \\
\hline \multicolumn{9}{|c|}{ Hybrid Krasnodar $382 \mathrm{MB}$} \\
\hline No irrigation & 4.6 & 5.7 & 1.9 & 2.8 & 2.1 & 2.9 & 2.8 & 3.8 \\
\hline With irrigation & 8.7 & 13.0 & 6.9 & 10.5 & 9.0 & 12.8 & 8.2 & 12.1 \\
\hline \multicolumn{9}{|c|}{ Hybrid Krasnodar 385 MB } \\
\hline No irrigation & 4.6 & 5.8 & 1.3 & 1.7 & 1.0 & 2.4 & 2.3 & 3.3 \\
\hline With irrigation & 9.1 & 13.4 & 6.7 & 10.2 & 9.4 & 13.6 & 8.4 & 12.4 \\
\hline $\mathrm{HCP}_{0.05}$ & \multicolumn{2}{|c|}{0.14} & \multicolumn{2}{|c|}{0.19} & \multicolumn{2}{|c|}{0.21} & \multicolumn{2}{|c|}{ - } \\
\hline
\end{tabular}

Note: in column 1 - no fertilizers; 2 - N90P120K60. 
Also, foliar top dressing of plants with a tank mixture of Kristalon $(3 \mathrm{~kg} / \mathrm{ha})+$ Brexil $\mathrm{Zn}$ $(0.15 \mathrm{~kg} / \mathrm{ha})+$ Carbamide $(7 \mathrm{~kg} / \mathrm{ha})$ fertilizers was effective. On average, over the years of studies in relation to the background, an increase in yield was obtained equal to $1.3 \mathrm{t} / \mathrm{ha}$ $(12.9 \%)$.

Table 3. The effect of fertilizers on the grain yield of the Beshtau hybrid corn under irrigation ( $t / h a)$

\begin{tabular}{|c|c|c|c|c|c|c|}
\hline \multirow{2}{*}{ Experience options } & \multirow{2}{*}{2015} & \multirow{2}{*}{2016} & \multirow{2}{*}{2017} & \multirow{2}{*}{ Average } & \multicolumn{2}{|c|}{ Increase } \\
\hline & & & & & $\mathrm{t} / \mathrm{ha}$ & $\%$ \\
\hline Fertilizer-free (control) & 8.5 & 8.5 & 7.6 & 8.2 & - & - \\
\hline N90P120K60 (Background) & 9.7 & 10.1 & 10.4 & 10.1 & 1.9 & 2.1 \\
\hline $\begin{array}{l}\text { Background }+ \text { top dressing Bioplant flora }(1.0 \text { l/ha } \\
\text { in } 5 \text { leaves }+2.01 / \text { ha in } 8 \text { leaves })\end{array}$ & 10.8 & 12.6 & 11.7 & 11.7 & 3.3 & 40.1 \\
\hline $\begin{array}{l}\text { Background + top dressing (Kristalon } 3.0 \mathrm{~kg} / \mathrm{ha}+ \\
\text { Brexil } \mathrm{Zn} 0.15 \mathrm{~kg} / \mathrm{ha}+\text { urea } 7 \mathrm{~kg} / \mathrm{ha} \text { ) }\end{array}$ & 11.2 & 11.2 & 11.7 & 11.4 & 2.5 & 28.0 \\
\hline $\begin{array}{l}\text { Background + top dressing (Kristalon } 3.0 \mathrm{~kg} / \mathrm{ha}+ \\
\text { Brexil Zn } 0.15 \mathrm{~kg} / \mathrm{ha}+\text { urea } 7 \mathrm{~kg} / \mathrm{ha})+ \text { seed } \\
\text { treatment Bioplant Flora }(1.0 \mathrm{l} / \mathrm{ha})\end{array}$ & 11.7 & 12.3 & 12.4 & 12.1 & 3.9 & 47.4 \\
\hline $\mathrm{HCP}_{0.05},(\mathrm{t} / \mathrm{ha})$ & 0.13 & 0.18 & 0.18 & 0.85 & - & - \\
\hline
\end{tabular}

The same option of use of fertilizers in combination with pre-sowing seed treatment with Bioplant Flora fertilizer gave the maximum increase in the grain yield of the Beshtau hybrid. Compared to the control without fertilizers, the yield increase was $3.9 \mathrm{t} / \mathrm{ha}(47.4 \%)$. Compared to application of mineral fertilizers to the soil, due to seed treatment and plant top dressing grain yield increased on average by $2.0 \mathrm{t} / \mathrm{ha}$ (by $19.8 \%$ ).

The effect on the yield of the hybrid was significant both for introduction of mineral fertilizers into the soil before sowing and use of fertilizers for seed treatment and plant top dressing during the growing season.

The offered options for the fertilization system influenced not only the grain yield, but also its quality. The lowest starch content in grain $(62.63 \%)$ was found in the control option of the experiment without fertilizers. Application of mineral fertilizers to the soil at a dose of N90P120K60 increased the starch content by $10.39 \%$. However, at the same time, compared with the control, the protein content in the grain decreased by $2.35 \%$. The most optimal option of the experiment, providing a simultaneous increase in both starch and protein, turned out to be a combination of mineral fertilizer with treatment of plants with the agrochemical Bioplant Flora at a dose of 1.0 1/ha in 5 leaves and 2.01/ha in 8 leaves.

Table 4. Chemical composition of corn hybrids (on average for 2015-2016)

\begin{tabular}{|c|c|c|c|c|c|}
\hline \multirow{2}{*}{ Index, \% } & \multicolumn{5}{|c|}{ Experiment option } \\
\cline { 2 - 6 } & 1 & 2 & 3 & 4 & 5 \\
\hline Starch & 62.63 & 73.02 & 72.08 & 65.91 & 67.6 \\
\hline Protein & 10.65 & 8.30 & 12.28 & 5.06 & 8.95 \\
\hline Fat & 5.59 & 5.45 & 5.46 & 5.80 & 5.67 \\
\hline Ash & 1.27 & 1.23 & 1.32 & 1.3 & 1.31 \\
\hline $\mathrm{N}$ & 1.70 & 1.33 & 1.96 & 1.63 & $1, .43$ \\
\hline $\mathrm{P}_{2} \mathrm{O}_{5}$ & 0.31 & 0.31 & 0.32 & 0.33 & 0.36 \\
\hline $\mathrm{K}_{2} \mathrm{O}$ & 1.96 & 1.45 & 1.41 & 1.99 & 3.34 \\
\hline
\end{tabular}

Note: 1 - Without fertilizers (control); 2 - $\mathrm{N}_{90} \mathrm{P}_{120} \mathrm{~K}_{60}$ - Background; 3 - Background + top dressing Bioplant Flora; 4 - Background + top dressing (Crystalon + Brexil + urea); 5 - Background + top dressing $($ Crystalon + Brexil + carbamide $)+$ seed treatment Bioplant Flora. 


\section{Conclusions}

1. Against the background of irrigation, application of mineral fertilizers at a dose of N90P120K60 in combination with pre-sowing seed treatment with the agrochemical Bioplant Flora $(1.0 \mathrm{l} / \mathrm{t})$ and foliar top dressing with a tank fertilizer mixture Kristalon $(3 \mathrm{~kg} / \mathrm{ha})+$ Brexil $\mathrm{Zn}(0.15 \mathrm{~kg} / \mathrm{ha})+$ urea $(7 \mathrm{~kg} / \mathrm{ha})$ showed the high efficiency in implementing the potential of the medium-late hybrid Beshtau. Due to irrigation and use of these fertilizers, the yield of the hybrid turned out to be possible to increase the yield of corn grain up to $12 \mathrm{t} / \mathrm{ha}$.

2. Application of mineral fertilizers to the soil at a dose of N90P120K60 in combination with foliar top dressing of plants with the agrochemical Bioplant Flora at a dose of $1.0 \mathrm{l} / \mathrm{ha}$ in 5 leaves and 2.0 $\mathrm{l} / \mathrm{ha}$ in 8 leaves increased the starch content in the grain from 62.63 to $72.08 \%$, protein - from 10.65 to $12.28 \%$.

\section{References}

1. V. V. Melikhov, I. P. Kruzhilin, N. V. Kuznetsova, Guidelines for the cultivation of corn for grain, Volgograd: State Institution Publisher, 88 (2003)

2. A. F. Stulin, Corn and sorghum, 1, 19 (2012)

3. G. N. Sukhoyarskaya, Productivity of hybrids of corn of different ripeness groups when using fertilizers on ordinary chernozem of the Central Ciscaucasia, 23 (2009)

4. V. N. Bagrintseva, I. N. Ivashenenko, Agrochemistry, 1, 72 (2018)

5. V. N. Bagrintseva, S. V. Nikitin, M. A. Cherkasova, Agrochemistry, 10, 46 (2019)

6. R. S. Sharifi, R. Taghizadeh, J. Food Agricult. Environ, 7(3-4), 518 (2009)

7. D. V. Lomovsky, Corn productivity depending on seed treatment with dressing agents, microfertilizers on leached chernozem of the Western Ciscaucasia, 24 (2007)

8. Z. P. Okazova, M. M. Tokbaev, Agricultural Science, 10, 22 (2008)

9. D. A. Taran, Productivity of corn hybrids depending on the pre-sowing application and top dressing with nitrogen and potassium humate on leached chernozem of the Western Ciscaucasia, 24 (2013)

10. Zh. M. Yakhtanigova, V. M. Kokova, New technologies, 5, 58 (2008)

11. Z. I. Usanova, I. V. Shalnov, Feed production, 2, 21 (2013)

12. A. I. Volkov, N. A. Kirillov, L. N. Prokhorova, Feed production, 7, 16 (2013)

13. V. N. Bagrintseva, Agrochemistry, 11, 47 (2015)

14. A. G. Amaeva, Implementation of the bioresource potential of highly productive corn hybrids of domestic and foreign selection, depending on the conditions of soil moisture in the steppe zone of the Chechen Republic, 18 (2013) 